\title{
THE FLORA OF THE CATAHOULA SANDSTONE.
}

\author{
By Edward Wilber Berry.
}

\section{INTRODUCTION.}

During the progress of my studies of the fossil floras of the Gulf Coastal Plain, embracing all horizons from the Lower Cretaceous to the Pleistocene and prosecuted under the general direction of T. Wayland Vaughan, material representing the floras of all the major stratigraphic units in the area extending from western Florida to central Texas has been discovered. Field work and office studies of all these floras have proceeded more or less simultaneously, and a large amount of manuscript in various stages of completion has been accumulated. The floras of the Upper Cretaceous and Eocene of South Carolina and Georgia have been described ${ }^{1}$ and a report on the very large lower Eocene floras is now in press. ${ }^{2}$

Because of their exceptional stratigraphic importance in solving some of the problems connected with the so-called "Grand Gulf complex" I was asked to submit a report on the fossil plants discovered within the limits of the Catahoula sandstone. This report was submitted in March, 1913. Since it was written a number of additional collections have been made from scattered localities, notably in eastern Texas, where through the cooperation of Mr. C. L. Baker, working under the supervision of Mr. E. T. Dumble, several important collections were obtained. It is my plan to discuss these several Coastal Plain floras exhaustively, as in the reports cited above, and for this reason it has been deemed inadvisable to endeavor to bring the description of the Catahoula flora entirely up to date at this time. In the following

\footnotetext{
1 Berry, E. W., The Upper Cretaceous and Eocene floras of South Carolina and Georgia: U. S. Geol. Survey Prof. Paper 84, 1914.

2 Berry, E. W., The lower Eocene floras of southeastern North America: U. S. Geol. Survey Prof. Paper 91 (in press).
}

pages only the more important discoveries that have been made since March, 1913, have been included. The plants from the Catahoula sandstone that still await description and illustration are largely represented by petrified wood, and until these remains are studied it will be impossible to determine whether any of the fossil plants obtained in western Louisiana and eastern Texas are of late Eocene (Jackson) age, although this seems to be very probable.

The uppermost Eocene, Oligocene, and lowest Miocene deposits of Europe have furnished very extensive fossil floras, several of which, such as those of the gypsiferous shales of Aix and other localities in southeastern France, ${ }^{3}$ of the lignites of Haering, in Tyrol, ${ }^{4}$ of Monte Promina, in Dalmatia, ${ }^{5}$ and of the Styrian lignites ${ }^{6}$ are classic.

In striking contrast to the abundant floras in Europe, very few plants of these ages have been found in North America, and practically nothing is known of the Oligocene floras of this continent. For this reason, as well as for the light it has shed on certain stratigraphic problems, the small flora in the Oligocene of the embayment area, from Texas eastward to western Mississippi, is of unusual interest, although it is in general poorly preserved and fragmentary.

The collection on which the present paper is based comes from ten localities. Six of these localities - 5 miles north of Jasper in Jasper County, Tex.; in Rapides and Grant parishes, La.; Washington, Adams County, Miss.; 5 miles north of Waynesboro, Wayne County,

3 Saporta, Gaston de, Études sur la végétation du sud-est de la France à l'époque tertiaire: Annales sci. nat., Botanique, 1862 to 1889.

${ }^{4}$ Ettingshausen, Constantin, Die tertiäre Flora von Häring in Tirol K. k. geol. Reichsanstalt Wien Abh., Bd. 2, Abt. 3, 118 pp., 31 pls., 1853. 5 Mainly elaborated by Ettingshausen, K. Akad. Wiss. Wien Denkschr., vol. 8, 1855.

6 Set forth in a large number of papers by Ettingshausen and Unger. 
Miss.; and on Bayou Pierre, Miss., near the Claiborne-Copiah county line-have furnished only the petrified remains of the wood of the very abundant tropical palms which clothed the shores of the Oligocene sea. The remains of identifiable leaves have been found at only four localities. Two small collections were made at the so-called Chalk Hills, 2 miles south of Rosefield, La., one by G. D. Harris ${ }^{1}$ and the other by me; a small collection was made by me near King, 5 miles south of Florence, Rankin County, Miss.; and a fourth collection came from Trinity County, Tex.

The species listed on page 230, 24 in number, have been identified from these 10 localities. These species include one fungus, two ferns, eight palms, a fig, an indubitable member of the family Proteaceæ (Embothrites), a species of pond apple or Anona, a species of rain tree (Pithecolobium), of the family Mimosaceæ; abundant remains of four varieties of satinwood (Fagara), of the family Rutaceæ; a species of Judas thorn (Paliurus), of the family Rhamnaceæ; another of coast myrtle or Myrcia, of the family Myrtaceæ; and two species of the family Sapotacex related to the genus Bumelia or iron wood. The collections include also fragmentary remains of other species that are too poor for satisfactory identification.

The most abundant and widely distributed elements in this Oligocene flora are the petrified remains of palm wood which are referred to the genus Palmoxylon and many of which are in an excellent state of preservation. Seven species are based on remains of this sort, and all seven of these species have been previously described by Felix, Stenzel, or Knowlton. A short paper by Knowlton ${ }^{2}$ on two species of palm wood from Rapides Parish, La., is the only previous contribution to the paleobotany of the Oligocene of this general region. All the other species are new to science.

Although this flora is too small to be representative, and the majority of the forms described have been found only in this region, nevertheless it furnishes decisive information on the physical conditions along the border of the Oligocene sea and also abundant data for

\footnotetext{
1 I am indebted to Mr. Arthur Hollick and the authorities of the New York Botanical Garden for the privilege of studying this collection.

2 Knowlton, F. H., Description of two species of Palmoxylon-one new-from Louisiana: U. S. Nat. Mus. Proc., vol. 11, pp. 89-91, pl. 30, 1888.
}

determining the approximate age of the deposits. As the climatic conditions which may legitimately be deduced from this assemblage form one of the factors used in correlation, this phase of the problem may be considered first. My studies during the last few years have resulted in the discovery of extensive Tertiary floras throughout southeastern North America, and although the descriptions of these floras have not yet been published, they have been rather fully worked out in manuscript. An enumeration at the present time shows a flora of 10 species in the Midway (?), 335 species in the Wilcox, about 75 species in the Claiborne, about 75 species in the Jackson (all Eocene), and 15 species in the Apalachicola (Oligocene). Fairly definite evidence regarding the climatic conditions of the border land is furnished by these floras, and this evidence is capable of being checked by the abundant marine faunas, so that what is said in the following paragraphs on the climate of Oligocene time is based not only on extensive comparisons between the Oligocene and the existing floras, but also on a knowledge of the floras of the epochs that immediately preceded and followed the Oligocene.

To turn now to the different units in this flora it may be noted that the fern genus Acrostichum is exclusively tropical in the existing flora, its most abundant species being the widespread Acrostichum aureum, a very gregarious inhabitant of coastal swamps, where it associates with mangroves and nipa palms. The existing species of the fern genus Lygodium, with but one exception, are inhabitants of coastal tropical thickets. The very great abundance and diversity of palms in the Oligocene flora also indicates tropical conditions, for although the study of palm woods has not reached a point where generic relationships can be positively affirmed, Stenzel, our foremost authority on palm anatomy, considers all these Oligocene species as most closely related to either Corypha or Cocos, and in addition several are present among the silicified woods of the island of Antigua, where tropical conditions must have prevailed throughout the Oligocene epoch. Ficus is not exclusively a tropical type, but of the 600 existing species a great majority are confined to the equatorial region and only a very few penetrate into the warmer parts of the Temperate Zone. The genus Embothrites 
is named from its resemblance to the existing genus Embothrium Förster and may or may not be strictly comparable with that genus. Embothrium has several species in the mountains of tropical Australia and in the Andean region of South America, from Peru southward into the Temperate Zone. It seems probable that the Tertiary genus is really a distinct member of the family Proteaceæ, which in the existing flora is largely tropical in its distribution. The genus Anona has about 50 existing species and occurs in all tropical countries. The greatest distance from the Equator that it reaches is shown by the species found on the Florida keys. The genus Pithecolobium of the family Mimosaceæ, has over 100 existing species, all of which are confined to the Torrid Zone.

The genus Fagara, which is so abundant at the Chalk Hills locality in Louisiana, has over 150 existing species, which are cosmopolitan in tropical and subtropical countries. The ecologic conditions at the locality where the Fagara leaves are so abundant are closely comparable with those prevailing at the present time in the lagoons behind the keys of southern peninsular Florida, where very similar species of Fagara are among the commonest of coastal plants. The sediments are, however, very different. At the Chalk Hills there are alternate layers of coarse sands and finely divided chert, but behind the Florida keys the deposits are calcium carbonate. The genus Paliurus, of which a small-leafed species is represented in the present collection, is almost entirely extinct at the present time, over 90 per cent of its known species being of Tertiary age. The two existing species are of warm temperate Eurasiatic habitats, but this fact lacks significance in the present connection, for the fossil forms are almost invariably associated with floras which must be regarded as at least subtropical. The genus Myrcia, represented by a single species in this Oligocene flora, inoludes over 400 existing species confined exclusively to the American Tropics and embracing many closely comparable coastal forms. The genus Bumelia, to which the two forms of Oligocene Sapotaceæ are related, is confined to America in the existing flora, embracing about a score of species distributed from northern Brazil through Central America and the West Indies to tho southern United States. Among these the form most similar to the fossil species is Bumelia horrida Grisebach, of the West Indies.

It will be seen from the foregoing enumeration that this fossil flora is strictly tropical in its facies-in fact, it must be regarded as the most tropical flora known from the Tertiary formations of the Southern States. This conclusion is borne out by a study of the associated marine faunas, which are regarded by Vaughan ${ }^{1}$ as indioating a bottom temperature between $70^{\circ}$ and $80^{\circ} \mathrm{F}$.

The flora contains no upland or inland types and may be regarded as a strictly coastal flora made up of groups comparable with those found along the strand in the present-day Tropics.

As bearing on the age of the deposits in which the flora here discussed has been found, it may be noted that this flora is of too tropical a character, even after allowances are made for my perhaps undue emphasis on its tropical aspect, to have been capable of existing during any post-Chipola epoch in our Southern States. This fact alone effectually disposes of the possibilities that the part of the so-called "Grand Gulf formation" immediately overlying the Vicksburg is of Pliocene or more recent age, as has been asserted by some students. Moreover, these deposits are interbedded with the Vicksburg limestone in Louisiana and immediately overlie it in central Mississippi, much of the petrified palm wood being found in depressions in the Vicksburg surface. At least one and probably two of the species of palm wood are common to the Oligocene of the island of Antigua. Another occurs in the Jackson of Louisiana, and a fourth in the Vicksburg of Alabama. Similarly the palm leaves referred to Sabalites vicksburgensis occur in the Jackson of Texas.

Finally the facies of the flora as a whole is that of the abundant floras found in the early Oligocene of southern Europe, notably in Provence, France, in Tyrol, and in Dalmatia and Styria. Not only does it exhibit this parallelism with these European early Oligocene floras, but when the genera are considered separately it appears that almost without exception they have not been found in what are now temperate latitudes in any beds younger than Oligocene.

1 Vaughan, T. W., A contribution to the geologic history of the Flo ridian Plateau: Carnegie Inst. Washington Pub. 133, p. 152, 1910. 
An exhaustive statement regarding the stratigraphic relations to one another of the several outcrops of the Catahoula at which fossil plants have been discovered is postponed

until the final report has been completed. Appended is a list of the species described in the following pages, with their stratigraphic position as determined by Mr. Matson.

Fossil plants from the Catahoula sandstone.

\begin{tabular}{|c|c|c|}
\hline Name. & Locality. & Horizon. \\
\hline 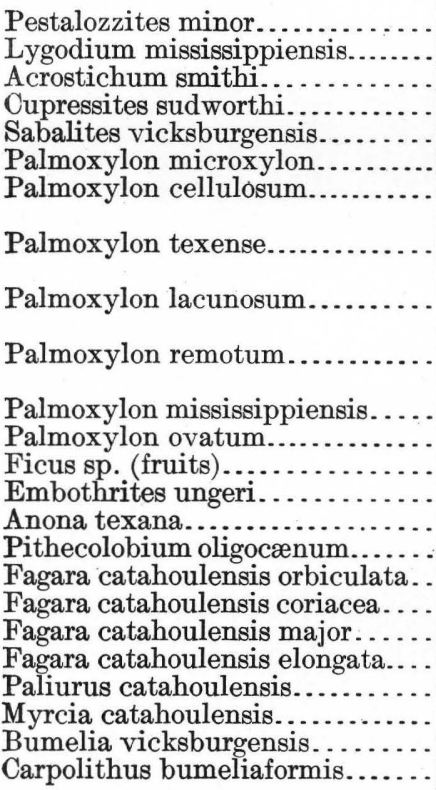 & 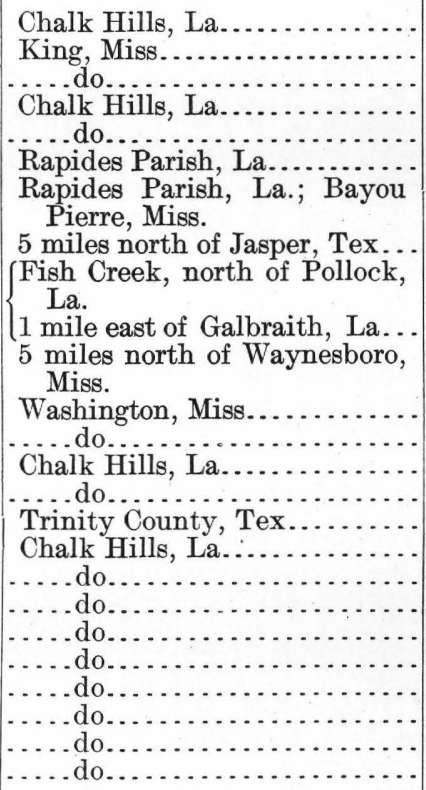 & $\begin{array}{l}\text { Catahoula sandstone (in beds of Vicksburg age). } \\
\text { Catahoula sandstone (in beds of Chattahoochee age). } \\
\text { Do. } \\
\text { Catahoula sandstone (in beds of Vicksburg age). } \\
\text { Do. } \\
\text { Catahoula sandstone (age ?). } \\
\text { Catahoula sandstone (in beds of Chattahoochee } \\
\text { age). } \\
\text { Catahoula sandstone (in beds of Vicksburg age). } \\
\text { Do. } \\
\text { Do. } \\
\text { Surface of Vicksburg. } \\
\text { Catahoula sandstone (age ?). } \\
\text { Do. } \\
\text { Catahoula sandstone (in beds of Vicksburg age). } \\
\text { Do. } \\
\text { Fayette sandstone (in beds of Jackson age). } \\
\text { Catahoula sandstone (in beds of Vicksburg age). } \\
\text { Do. } \\
\text { Do. } \\
\text { Do. } \\
\text { Do. } \\
\text { Do. } \\
\text { Do. } \\
\text { Do. } \\
\text { Do. }\end{array}$ \\
\hline
\end{tabular}

THE FLORA.

\section{Phylum THALLOPHYTA.}

Fungi imperfecti.

Order MELANCONIALES.

Family MELANCONIACER.

Genus PESTALOZZITES Berry, n. gen.

The genus Pestalozzites is proposed for fossil leaf-spot fungi that attacked fan palms and formed nondiffuse spots with plainly marked outlines and more or less regular form. It was suggested by the identity in appearance between Pestalozzites sabalana Berry (manuscript name) and Pestalozzia sp.cf. P. palmarum Cooke $^{1}$ found infesting Serenoa serrulata (Michaux) Hooker. I fully realize that appearances are deceptive and that there are a large number of parasitic fungi which attack existing palms, as, for example, species of the genera Ascochyta, Diplodia, Exosporium, Phoma,

\footnotetext{
1 Kindly identified for the writer by Mrs. Flora W. Patterson, of the Bureau of Plant Industry, U. S. Department of Agriculture.
}

Pleospora, and Stagonospora, any of which might cause leaf spotting. The name given may well serve, however, as a form genus for remains of this sort and no harm is done in commemorating the resemblance to the existing genus Pestalozzia De Notley, the only modern genus whose effects are so regular in appearance.

In a considerable amount of fossil material the characteristic spotting of this type is mainly confined to the leaf rays of a Saballike form, but in the Claiborne species Thrinax eocenica Berry it occurs on both the rays and the rachis.

\section{Pestalozzites minor Berry, n. sp. \\ Plate LV, figure 2.}

Essential characters unknown. Found infesting the rays of Sabalites vicksburgensis Berry, where it forms relatively small, usually nearly circular leaf spots, which average about 1 millimeter in diameter. These remains are of trifling value from either the botanist's 
or the geologist's point of view, nevertheless they are of considerable interest as indicating the presence of this type of plant life in the Oligocene epoch. Indistinguishable remains are present on both the rays and the rachis of the Claiborne species Thrinax eocenica Berry.

Occurrence: Catahoula sandstone, Chalk Hills, 2 miles south of Rosefield, La.

Collection: New York Botanical Garden.

\section{Phylum PTERIDOPHYTA.}

Order FILICALES.

\section{Family SCHIZEACEA.}

Genus LYGODIUM Swartz.

Lygodium mississippiensis Berry, n. sp.

Plate LV, figures 3,4 .

Pinnules small and somewhat coriaceous, bilobate. Base rounded. Margins entire, slightly undulate. Lobes narrow, linear, with rounded tips, diverging at an angle of about $90^{\circ}$ and separated by a right-angled sinus that approaches within 6 or 7 millimeters of the base. Width of lobes about 7 millimeters; length about 3 centimeters. Venation characteristic of the genus; rather open, considering the small size of the pinnules. At or just above the base the leaf trace of the pinnule forks at an angle of $55^{\circ}$ to $66^{\circ}$, the branches curving outward and pursuing a course approximately in the middle of the lobes until they become obsolete by repeated branching. The branches go off at acute angles and curve outward, forking one or more times (usually but once) by a narrow dichotomy and ending in the margin.

The present species is based on very scanty and fragmentary remains found also in the Fayette sandstone of Trinity County, Tex. It is fully recognized that Lygodium pinnules are in general variable in size, outline, and lobation and that the foregoing description is inadequate in many respects. At the same time this species represents a characteristic element in a meager flora which is of great interest to the student of comparative paleobotany. It is clearly distinct from the Wilcox or Claiborne species of Lygodium, the tendency seemingly having been in the direction of a progressive diminution in the size of the pinnules, a feature also noted in the records of the species of Lygodium found in the Tertiary of Europe.
It resembles somewhat but is perfectly distinct from Lygodium dentoni Lesquercux, ${ }^{1}$ of the Green River formation in the Rocky Mountain region. It also resembles what J. Starkie Gardner terms a "dwarfed barren frond of Lygodium kaulfussi Heer from the Lutetian of southern England." 2 Saporta has described three species from the Sannoisian of southern France, a horizon not very different from the present one, which greatly resembles this species. They are Lygodium parvifolium, ${ }^{3} \mathrm{~L}$. exquisitum, ${ }^{4}$ and L. distractum. ${ }^{5}$ Lygodium parvifolium is a small bilobate form very close to the present specics; in fact, the two may be identical, but in the present state of our information, both species being rare and scantily represented, it is wiser to keep them distinct.

Occurrence: Catahoula sandstone near King, 5 miles south of Florence, Rankin County, Miss.

Collection: United States National Museum.

Family POLYPODIACER.

Genus ACROSTICHUM Linnê.

Acrostichum smithi Berry, n. sp.

Plate LV, figures 5-8.

Frond habit undeterminable, presumably pinnate and of large size. Pinnæ variable in size and outline, ranging from reduced elongate-elliptical pinnæ like those of the Claiborne-Jackson species Acrostichum georgianum Berry to forms with long, narrow pinnæ and other forms with pinnæ fully as large as those of the Yegua or "Cockfield" (upper Claiborne) and Green River species Acrostichum hesperium Newberry. The margins are entire but somewhat irregular and more or less revolute. The leaf substance is thick and the texture coriaceous, much more so than in either of the forms cited. Midrib stout and more or less flexuous. Lateral venation very fine and obsoure, of the typical Acrostichum type, more ascending than in the species

1 Lesquereux, Leo, Contributions to the fossil flora of the Western Territories, pt. 2, The Tertiary flora: U.S. Geol. Survey Terr. Rept., vol. 7 , p. 63 , pl. 65 , figs. $12,13,1878$.

2 Gardner, J. S., and Ettingshausen, Constantin, British Eocen $\Theta$ Flora, vol. 1, p. 67, pl. 13, fig. 8, 1882 .

3 Saporta, Gaston de, Études sur la végétation du sud-est de la France à l'époque tertiaire, vol. 3 , suppl. 2 , p. 87 , pl. 1, fig. 14, 1867; Dernières adjonctions à la flore fossil d'Aix-en-Provence, pl. 2, fig. 6, 1889.

4 Saporta, Gaston de, op. cit. (Études, etc.), p. 88, pl. 1, fig. 13

5 Saporta, Gaston de, op. cit. (Dernières adjonctions, etc.), pt. 1, p. 24 , pl. 2 , fig. 8 . 
cited, with very narrow and much elongated areolæ.

This species is abundant but fragmentary in the Mississippi Oligocene, where the matrix is an argillaceous sand or sandy mudstone of shallow-water origin and not especially favorablo for the preservation of plant remains. Somo years ago Dr. Eugene A. Smith showed me a nearly complete pinna about 12 centimeters in length that he had collected from this locality. I have not seen this specimen recently but presume it is still in the collections of the Alabama Geological Survey at University, Ala. The species is named for Dr. Smith, who has done so much for southern geology and who discovered the plant locality near King, Miss., that makes it possible to correlate the deposits definitely.

The genus Ácrostichum is made up of tropical marsh ferns, its most representative species being Acrostichum aureum Linné, a cosmopolitan and common tropical and subtropical type inhabiting the mangrove and nipa tidal swamps as well as similar situations throughout the old and new worlds. The genus appears in the basal Eocene and has several European and American species in Eocene and Oligocene deposits, the principal forms being Acrostichum lanzeanum (Gardner and Ettingshausen) ${ }^{1}$ of the European Lutetian and Bartonian, and Acrostichum georgianum Berry and Acrostichum hesperium Newberry, of the Claiborne, Jackson, and Green River deposits. Several other species from the European Oligocene (Sannoisian, Tongrian, and Chattian) that are comparable with the present form have been described. The present species is especially like Acrostichum strictum (Squinabol), of the Lower Tongrian of Ste. Justine, near Savone, in Liguria, Italy.

Occurrence: Catahoula sandstone near King, 5 miles south of Florence, Rankin County, Miss.

Collection: United States National Museum.

1 Gardner, J. S., and Ettingshausen, Constantin, British Eocene flora, vol. 1, p. 26, pl. 1; pl. 2, figs. 1-4, 1879.
Phylum SPERMATOPHYTA.

Class GYMNOSPERMA.

Family PINACER.

Genus CUPRESSITES Bowerbank.

Cupressites sudworthi Berry, n. sp.

Plate LV, figure 1.

Cones small, subglobose, 1.5 to 2 centimeters in diameter. Cone scales ligneous, decussate, less than 10 in number, the exact number not determinable, peltate in form, with a thick axis abruptly dilated to the subangular four or five sided, expanded and transversely flattened tip, which is thick and radiately wrinkled from the subcentral mucronate umbo.

The present species is based on poorly preserved and somewhat crushed cones, whose substance at the Chalk Hills locality is replaced by a friable kaolinitic deposit. No traces of coniferous foliage have been found in association with them. These cones are very similar to those from the Lower Oligocene of Haering, in Tyrol, described by Unger $^{2}$ as Cupressites taxiformis, which Gardner, ${ }^{3}$ apparently on good grounds, transfers to the genus Cupressus and associates with cones from the supposedly older beds at Bournemouth (Middle Bagshot), in the south of England. The present material is too poorly preserved to show whether the proximal scales are fused or free, or whether sterile scales persist at the base of the cone. As identity with Cupressus taxiformis can not be positively established these remains are described as new, and as they can not be definitely referred to the genus $\mathrm{Cu}$ pressus rather than Chamæcyparis, they are referred to the form genus Cupressites of Bowerbank and named in honor of $\mathrm{Mr}$. George B. Sudworth, of the United States Forest Service. The species in a lignified state is present in beds of lower Jackson age in western Tennessee.

2 Unger, Franz, Chloris protogæa, p. 18, pl. 8, figs. 1-3; pl. 9, figs. 1-4, 1847.

3 Gardner, J. S., British Eocene flora, vol. 2, p. 26, pl. 9, figs. 22-26, 28-30, 1883. Other figures show the characteristic dimorphic foliage. 
The modern species of Cupressus are about 12 in number, of comparatively warm climatic requirements, found in southern Eurasia and in Pacific North America from California southward to Central America, usually frequenting sandy habitats near the coast. The modern species of Chamæcyparis number four or five and are confined to the Atlantic and Pacific coast regions of North America and similar, mostly swampy habitats in Japan and Formosa.

Occurrence: Chalk Hills, 2 miles south of Rosefield, La.

Collection: United States National Museum.

Class ANGIOSPERMA.

Subclass MONOCOTYLEDONÆ.

Order ARECALES.

Family ARECACE正.

Genus SABALITES Saporta.

Sabalites vicksburgensis Berry, n. sp.

Leaves of variable size, flabellate, the maximum diameter estimated (from collected material) at about 120 centimeters. Rachis relatively slender, unarmed, not enlarged at the base of the leaf, continued upward as a long, slender, gradually narrowed acumen. Whether or not the two surfaces of the leaf differ, as they do in Sabalites grayanus Lesquereux, of the Wilcox, and Sabalites apalachicolensis Berry, of the Apalachicola group, can not be determined from the available material. Fragmentary counterparts of the base of a leaf indicate that the acumen is practically the same on both leaf surfaces. Rays carinate, about 40 in number; basal ones becoming smaller, narrower, closer, and more curved proximad; all are extended, linear-lanceolate, and acuminate, becoming free distad for greater or less distances, usually from one-third to one-half their total length. Maximum observed width of rays (near the middle), 3.6 centimeters. Midrib of rays stout. Lateral veins parallel with midrib, stout, about 30 on each side, one or two at irregular intervals on each side more prominent than their fellows, connected by fine transverse veinlets at right angles to the main parallel venation. Leaf substance relatively thin but stiff.
The present species is close to previously described forms of Sabalites, the specific relations of all of which are not certainly assured. It differs from Sabalites apalachicolensis Berry (unpublished) in its more slender rachis, longer acumen, thinner leaf, and more prominent venation. It may be distinguished from the widespread Wilcox form Sabalites grayanus Lesquereux by its more slender rachis, lack of enlargement at the base of the leaf, and thinner texbure.

Sabalites vicksburgensis was a form that resembled in its habitat Sabalites apalachicolensis as well as the modern Sabal palmetto Roemer and Schultes - that is to say, it probably never flourished far from the coast. It is represented in the collections by little first-class material, although the numerous ray fragments in the argillaceous sandstones of the Chalk Hills show that it must have been an abundant element in the flora of Vicksburg time. The Vicksburg is notable for the abundance of petrified fragments of palm stems found in its deposits and distributed in an arc extending from Texas through Louisiana, Mississippi, and Alabama, and probably reaching the West Indies on the one hand and Mexico on the other. Seven different species based on these remains are described in the present study and bear eloquent testimony to the diversity of the palm flora and to the tropical character of the Vicksburg climate. Some of the Chalk Hills rays are infested with a leaf-spot fungus which I have described as Pestalozzites minor.

Occurrence: Catahoula sandstone, Chalk Hills, 2 miles south of Rosefield, La.

Collection: United States National Museum.

\section{Genus PALMOXYLON Schenk.}

Palmoxylon. Schenk, Engler's Bot. Jahrb., vol. 3, p. 355, 1882.

The silicified remains of palm wood are exceedingly common in the late Eocene and Oligocene deposits from Texas eastward across Louisiana, Mississippi, and Alabama, and reappear in several of the Greater and Lesser Antilles, as well as in Mexico and on the Isthmus of Panama. These remains are fragmentary for the most part, although several large trunks have been seen. Usually they are found weathered out upon the surface, or 
reworked and more or less rolled, in Pleistocene and Recent deposits, in or immediately south of the area of outcrop of the Vicksburg deposits.

In the early days fossil palm wood was referred to the genera Fasciculites Cotta and Endogenites Brongniart or Palmacites Brongniart, but Schenk, who made extensive contributions to this subject, united all the remains in the comprehensive form genus Palmoxylon, in which he has been followed by most subsequent writers. More recently two other German students, Felix and Stenzel, have devoted much time to the elucidation of petrified palm wood from various parts of the world. Stenzel has given us the most comprehensive work on the subject ${ }^{1}$ that has yet appeared, in which 62 species of wood and 4 species of roots are elaborately described and figured, and extended comparisons are instituted between the fossil and living species of palms.

The difficulties in the way of satisfactory systematic work on the internal structure of the Monocotyledonæ are very much greater than with the Gymnospermæ or the Dicotyledonæ. Not only are satisfactorily preserved specimens of fossil forms much rarer, by reason of their parenchymatous nature, but there is less characteristic generic variation among the palms, and furthermore the present state of our knowledge of the anatomy of the existing species is in a very unsatisfactory condition.

Felix, in his studies, divided palm woods into two sections-one in which small round sclerenchyma bundles are scattered through the stem parenchyma between the fibrovascular bundles, and one in which these auxiliary sclerenchyma bundles are lacking. Stenzel departs somewhat from this older method and uses a system based largely on a comparison of the arrangement, size, and structure of the bundles in the central and peripheral portions of the stem, and on the size and shape of the sclerenchyma portion of the fibrovascular bundles.

In the present connection no attempt is made to review the literature on fossil palms or on the anatomy of recent palms, the arrangement and supposed affinities as determined by Stenzel being followed without any attempts at revision. The following key will facilitate the determination of remains of this sort:

1 Stenzel, K. G., Fossile Palmenhölzer: Beitr. Pal. Geol. ÖsterreichUngarns u. des Orients, vol. 16, pt. 4, pp. 1-182, pls. 1-22, 1904.
Key of Oligocene species of Palmoxylon of southern United States.

Fibrovascular bundles all similar-that is, without perceptible differences between those of the central and pəripheral regions of the stem; parenchyma without intercellular spaces:

Sclerenchyma portion orbicular or ovate in cross section, either truncate or with a broad, shallow indentation where it joins the vascular portion (reniform)...............................

Sclerenchyma portion deeply excavated (lunate) to receive the vascular portion, which is approximately equal to it in size. Fibrovascular bundles thin, 0.5 millimeter, close-set, uniformly distributed. No auxiliary bundles. .mississippense. Fibrovascular bundles usually crowded in the peripheral region, more remote centrally; sclerenchyma portion strongly developed,- usually much larger than the vascular portion:

Parenchymatous groundmass with intercellular spaces:

With auxiliary sclerenchyma bundles:

Fibrovascular bundles unsymmetrically arranged, crowded, sclerenchyma portion round. Auxiliary bundles rare, naked. Intercellular spaces not well defined in peripheral portion of stem........................exense.

Auxiliary bundles numerous, thin, naked. Parenchyma with prominent intercellular spaces............ lacunosum.

Without auxiliary sclerenchyma bundles:

Sclerenchyma portion of fibrovascular bundles sagittate or almost surrounding the reduced vascular portion....cellulosum.

Vascular portion orbicular or ovate, not in an embayment of the sclerenchyma portion; where the latter joins the former it is flattened (complanate).. remotum. Groundmass without intercellular spaces.. microxylon.

Corypha-like stems.

Group SAGITTATA.

Palmoxylon microxylon (Corda) Stenzel.

Palmacites microxylon. Corda, Beiträge zur Flora der Vorwelt, p. 48, pl. 21, 1845.

Fasciculites Cottæ. Unger, Genera et species plantarum fossilium, p. 335, 1850.

Fasciculites didymosolen. Stenzel, De trunco palmarum fossilium (Inaug. diss.), p. 8, 1850.

Palmoxylon Quenstedti. Felix, Die fossile Hölzer Westindiens, p. 25, pl. 4, fig. 4, 1883.

Palmoxylon Quenstedti. Knowlton, U. S. Nat. Mus. Proc., vol. 11, p. 90 , pl. 30 , fig. 1, 1888.

Palmoxylon microxylon. Stenzel, Fossile Palmenhölzer, p. 68 (174), pl. 15 (17), figs. 160, 168, 1904.

Fibrovasoular bundles thick, numerous, closely spaced, irregular in outline in transverse sections, 0.5 to 1 millimeter in diameter; the sclerenchyma portion strongly developed, 
consisting of exceedingly thick walled cells, often nearly and sometimes entirely surrounding the vascular portion, which consists of a few large or several small vessels; the phloem and xylem parenchyma often poorly preserved. The vascular portion generally occupies a usually angular and often narrow indentation in the basal portion of the handle. Bundles somewhat less numerous in central part of stem. Auxiliary sclerenchymatous bundles numerous, relatively stout, 0.16 to 0.08 millimeter in diameter, not surrounded by a ring of small, longitudinally elongated parenchymatous cells. Groundmass without well-defined intercellular spaces; made up of rather small, thin-walled, usually longitudinally elongated, occasionally isodiametric and parenchymatous polyhedral cells; those in close proximity to bundles radially widened.

This species has been fully discussed by Stenzel. It was described as early as 1845 by Cordafrom materialfound in the Oligocene of the island of Antigua and was collected in 1885 by L. C. Johnson in Rapides Parish, La., the exact locality being unrecorded. It has not been found in this region by the more recent collectors.

Occurrence: Catahoula sandstone, Rapides Parish, La.

Collection: United States National Museum.

\section{Palmoxylon cellulosum Knowlton.}

Palmoxylon cellulosum. Knowlton, U.S. Nat. Mus. Proc., vol. 11 , p. 90 , pl. 30, fig. 2, 1888.

Palmoxylon cellulosum. Felix, Fossile Hölzer von Tlacolula, p. 3 (46), pl. 3, figs. 1-3, 1893.

Palmoxylon cellulosum. Stenzel, Fossile Palmenhölzer, p. 72 (178), pl. 15 (17), figs. 169-171; pl. 16 (18), figs. 172-184, 1904.

Fibrovascular bundles large, elliptical in transverse section, about 1 millimeter in diameter; sclerenchyma portion nearly surrounding the vascular portion. Groundmass of large irregular parenchymatous cells, with large intercellular spaces; somewhat more compact in the immediate vicinity of the bundles. The fibrovascular bundles are more numerous in the peripheral than in the central part of the stem, but much less crowded than in Palmoxylon microxylon. The ground tissue greatly resembles that of $P$. lacunosum but lacks the auxiliary sclerenchyma bundles of that species.

Palmoxylon cellulosum, as described by Knowlton, came from Rapides Parish, La. Subse- quently it was recorded from the State of Oaxaca, Mexico, by Felix, who supposed the strata containing it to be Cretaceous. Either the age determination of the Mexican strata was erroneous or the two occurrences can not represent the same species. Additional material of this species has been collected from Bayou Pierre in Mississippi.

Occurrence: Catahoula sandstone, Rapides Parish, La.; Bayou Pierre, Claiborne-Copiah county line, Miss.

Collection: United States National Museum.

Group COMPLANATA.

\section{Palmoxylon texense Stenzel.}

\section{Plate LVI.}

Palmoxyıon texense. Stenzel, Fossile Palmenhölzer, p. 79 (185), pl. 6 (8), figs. 61-63, 1894.

Stenzel correlated two specimens from Texas with this species, regarding one as a peripheral part of a stem and the other as a more central portion. These he describes as follows:

The ground tissue in both is formed from thin-walled cells; the exterior is dense or at least without well-defined intercellular spaces. The sclerenchyma portion of the longitudinal bundle is surrounded with two or three layers of rather small elongated cells, arranged with their major axes parallel, followed by larger elongated cells which are radially disposed with their short sides toward the fibrous tissue. In the woody fiber, on the contrary, the cells are almost uniformly polygonal; only in isolated areas do any number of even slightly elongated cells occur. The fundamental tissue from the central part of the stem is, on the other hand, porous, with numerous intercellular spaces. Pressed close against the sclerenchyma portion, as in the outer bundles, are well-developed elongated cells which radiate from the woody part, and outside of these are several layers of similar cells connected with each other, which often exhibit a symmetrical orientation toward the middle of the stem.

The outer longitudinal fibrovascular bundles run straight upward; they are placed near one another-in fact, whole series lie so close that they are almost in contact, and 45 or 50 are crowded into a single square centimeter. Within they even lie on top of one another, but toward the middle of the stem they are separated by interspaces two or three times their own thickness, so that only a dozen fibrovascular bundles occur in the same space; and yet almost all the longitudinal bundles, like the small transverse bundles, direct their sclerenchyma portion, sometimes horizontally, sometimes a little obliquely, toward the exterior, so that we must take it for granted that we have before us, in addition, a part of the intermediate layer. It is very remarkable that among the outer longitudinal bundles only a small fraction are unsymmetrically arranged.

The longitudinal bundles are obviously binary. The roundish sclerenchyma portion, of very thick walled cells, is somewhat flattened toward the inside, even squeezed 
very thin, but laterally it is rounded. At this point the smaller vascular portion is generally attached; this is usually elongated near the outer bundles and frequently produced behind so that it appears almost triangular in outline, while within it is rounded to form a semicircle in cross section. It bears two discrete vascular bundles either one of which may be replaced by two others, similar in character, situated near at hand.

The transverse bundles, in which the breadth of the fibrous portion is equal to or less than the breadth of the longitudinal bundles, have a simple yet narrower, more produced woody portion.

The few auxiliary sclerenchyma bundles are of not more than medium thickness. They are uniformly distributed, thin, and without encircling cells.

Stenzel does not give the exact locality in Texas where his material was collected, but it is not unlikely to have come from the same area in Jasper County as my material. Unstudied material indicates the probable presence of this species at several localities in the Catahoula sandstone of Texas and in the Vicksburg limestone of Alabama.

Occurrence: Catahoula sandstone, 5 miles north of Jasper, Jasper County, Tex.

Collection: United States National Museum.

\section{Palmoxylon lacunosum (Unger) Felix.}

Plate LVII, figure 1; Plate LVIII.

Fasciculites lacunosus. Unger, in Martius, Genera et species palmarum, vol. 1, p. 58, sec. 16, tab. geol. 1, fig. 1 ; 2 , fig. 8 ; 3 , fig. 1 , 1845; Synopsis plantarum fossilium, p. 186, 1845; Chloris protogæa, p. 71, 1845; Genera et species plantarum fossilium, p. 335, 1850.

Palmoxylon lacunosum. Felix, Die fossile Hölzer Westindiens, p. 23, pl. 5, fig. 3, 1883. [1882 name is referred by Stenzel to $P$. anomalum (Unger).]

Palmoxylon lacunosum. Stenzel, Fossile Palmenhölzer, p. 81 (187), pl. 8 (6), figs. 64-66, 1904.

Palmoxylon lacunosum. Schenk, in Zittel, Handbuch der Palaeontologie, Abth. 2, Palaeophytologie, p. 889, fig. 430,1890 .

Fibrovascular bundles not crowded, especially in interior of stem; sclerenchyma portion ovate or reniform in transverse section. Vascular portion orbicular. Auxiliary sclerenchyma, bundles numerous, thin, without modified encircling cells. Groundmass with intercellular spaces, which are not greatly developed in the peripheral part of the stem.

Stenzel refers the following forms to this species:

Fasciculites anomalus. Unger, in Martius, op. cit., p. 57, pl. 2, fig. 9 ; pl. 3, fig. 2, 1845. (This reference, if correct, would, according to the law of priority, involve a change in the name of this well-known form.)
Palmacites axonensis. Watelet, Plantes fossiles du bassin de Paris, p. 103, pl. 30, fig. 3, 1866. (From Quincysous-le Mont, in the valley of the Aisne.)

The species is close to Palmoxylon texense and also to $P$. antiguense. The original locality is unknown, although the species is often referred to the island of Antigua, as by Schenk. My Catahoula material is abundant, but not especially well preserved. Very well preserved material occurs in the Vicksburg at Nero, Ala.

Occurrence: Catahoula sandstone, Texas \& Pacific Railway, 1 mile east of Galbraith, northwest border of Rapides Parish, La.; south bank of creek just north of Pollock, Grant Parish, La.

Collection: United States National Museum.

\section{Palmoxylon remotum Stenzel.}

Plate LVII, figures 2-5.

Palmoxylon remotum. Stenzel, Fossile Palmenhölzer, p. 91 (197), pl. 7 (9), figs. 79-81; pl. 8 (10), fig. 82; pl. 9 (11), figs. 83-85, 1904.

Fibrovascular bundles thick, 1 millimeter in diameter, rather widely spaced; sclerenchyma portion elliptical to reniform in transverse section, flattened where it joins the orbicular relatively large vascular portion, which consists of a few large vessels and several small ones. Auxiliary sclerenchyma bundles wanting. Groundmass of elongated cells with intercellular spaces, except in the immediate vicinity of the fibrovascular bundles, where they are closer and radiately arranged.

This species is readily distinguished from associated forms by the large size and remoteness of the fibrovascular bundles, coupled with the absence of auxiliary bundles. It was described by Stenzel from specimens collected near Washington, Adams County, Miss. I discovered a fragment over 30 centimeters in diameter and 75 centimeters in length in the possession of a native of Waynesboro, in the eastern part of Mississippi. It was collected from the surface of the ground about 5 miles north of Waynesboro, in a depression of the Vicksburg limestone and is now in the collection of the Geological Survey of Mississippi. Dr. E. $\mathrm{N}$. Lowe, the State geologist, kindly forwarded fragments to me for study.

Occurrence: Catahoula sandstone, Washington, Adams County, Miss.; 5 miles north of Waynesboro, Wayne County, Miss. 
Collections: United States National Museum, Mississippi Geological Survey, Gustar Stenzel in Breslau.

Cocos-like stems.

Group LUNARIA.

Palmoxylon mississippense Stenzel.

Palmoxylon mississippense. Stenzel, Fossile Palmenhölzer, p. 142 (248), pl. 21 (23), figs. 254-265, 1904.

I have not seen any specimens of this species, and the following is a free translation of some of Stenzel's comments on it:

The curved and irregular course of the Iongitudinal bundles, as well as the change in relative position of sclerenchyma and vascular portions, the relatively large size of the vascular portion, which equals that of the sclerenchyma portion, and the slight disparity between the size of the transverse and that of the longitudinal bundles all give evidence of the fact that the specimen is from the central part of a stem.

The groundmass consists of thin-walled, closely locked cells which are small and elongated only in proximity to the fibrovascular bundles and in the narrow interspaces between two adjacent bundles; elsewhere they are polygonal and reach 0.04 millimeter in width.

The longitudinal bundles are uniformly distributed and are separated from each other by interspaces approximately equal to their semidiameter, though occasionally they stand farther apart. At the same time they are so small, with a maximum diameter of scarcely 1 to 2 millimeters, that as many as 300 have been found in 1 square centimeter.

Because of the very different directions in which they are turned, more than one-half lie within a quarter circle, so that these can be looked upon as directed toward the exterior; the directions of the cross and of the transverse bundles are, however, very diverse, and the course of the bundles is bent now this way and now that, so that the most plausible theory still seems to be that we have before us a part of the central portion of the stem. This would also accord with the assumption that this belongs to a Cocos-like form.

The outline of the longitudinal bundle is somewhat distorted in the figures, and the oval as well as the cross and the various oblique sections of the same bear witness to the weathering of the fossil, as does also the frequent pitting of the veins and even more strongly the discrepant stratification of the bundles. Then, too, we find that the vascular portions of the bundles, which are ordinarily pressed flat against the sclerenchyma portions, have been warped to one side just as we have seen them elsewhere.

These same causes account for the polymorphism of the sclerenchyma portion in the groundmass, in which we find as a prevailing peculiarity that the outer boundary is a semicircle, while within it borders upon the vascular bundle with an almost horizontal contact line excepting for a flattened contraction near the middle. In many bundles this contraction is more sharply defined, its margins more angular, and it is often more restricted on one side than on the other. In only a few is the margin obtuse or even somewhat rounded. In that case the ordinary lunar outline is not wholly obscured. The cells of the sclerenchyma portion are uniform and polygonal, with thickened walls, leaving, however, a moderately large lumen.

This species is very similar to Palmoxylon palmacites (Sprengel) Stenzel, ${ }^{1}$ which occurs in the Oligocene of Antigua and of the Canal Zone.

Occurrence: Catahoula sandstone, Washington, Adams County, Miss.

Collection: Gustar Stenzel in Breslau.

\section{Group RENIFORMIA.}

Palmoxylon ovatum Stenzel.

Palmoxylon ovatum. Stenzel, Fossile Palmenhölzer, p. 119 (225), pl. 14 (16), figs. 152-158, pl. 15 (17), fig. 159, 1904.

This species, like Palmoxylon mississippense, is unrepresented outside of Prof. Stenzel's collection. It may be briefly described as follows: Fibrovascular bundles thick, closely and somewhat irregularly spaced; sclerenchyma portion orbicular, ovate or elliptical in transverse section, truncated or with a shallow indentation where it joins the vascular portion, which is well developed and often as large as the sclerenchyma portion; rhomboidal in transverse outline. Auxiliary bundles not abundant, without modified encircling cells. Groundmass without intercellular spaces. A distinguishing feature of this species is the occurrence in transverse sections of tiny scattered dark spots resembling the smaller auxiliary sclerenchyma bundles of Palmoxylon lacunosum. They show no structure and of ten lie in juxtaposition with the fibrovascular or auxiliary bundles.

Stenzel compares the structure of this form with that of existing forms of Mauritia and Geonoma. Among fossil species it is said to be most similar to Palmoxylon cottæx (Unger) Felix, a species occurring in the Oligocene of the West Indies and Italy and in the upper Eocene or lower Oligocene of Egypt (Libya). Occurrence: Catahoula sandstone, Washington, Adams County, Miss.

Collection: Gustar Stenzel in Breslau.

1 Stenzel, Gustav, Fossile Palmenhölzer, p. 245, pl. 20, fig. 253, 1904. 
Subclass DICOTYLEDONA.

Order URTICALES.

Family MORACE曆.

Genus FICUS Linnê.

Ficus sp.

Plate LV, figure 9.

The remains of a single fruit of some species of Ficus is contained in the collections from the argillaceous sandstones of the Chalk Hills, La. It may be characterized as follows: Fruit obovate in lateral view, circular in cross section, with a rounded apex, tapering downward to the short and thick peduncle. Length about 2.5 centimeters; maximum diameter in the upper part, about 1.5 centimeters. Peduncle about 4 millimeters in length. Outer surface rough with irregular longitudinal ridges. Texture somewhat leathery.

This fruit clearly represents a small, semifleshy fruit of some species of fig, as yet unrepresented by foliage, which flourished on the Vicksburg strand. It is closely comparable with the fruits of many existing species of figs and is not unlike several fossil fruits which have been described. As the majority of fossil species are based on foliage, which is exceedingly abundant in Tertiary floras everywhere, I have not ventured to give the present form a specific name.

Occurrence: Catahoula sandstone, Chalk Hills 2 miles south of Rosefield, La.

Collection: New York Botanical Garden.

\section{Order PROTEALES.}

Family PROTEACE正.

Genus EMBOTHRITES Unger.

Embothrites ungeri Berry, n. sp.

Plate LV, figures 11, 12.

Seed unsymmetrical, roughly triangular in outline, somewhat flattened, produced into a conical point at the chalazal end, rounded distad and at the inner angle, where an elliptical hollow represents a depression made by pressure of the adjacent seed. Fruit evidently capsular, as indicated by the contour of the seed, which shows that the capsule contained several closely packed seeds. Seeds winged. Wing rather firm, broad, abruptly rounded, with about 20 thin subparallel longitudinal veins. Length of seed about 7 millimeters; maximum width about 3.5 millimeters. Proximal spur about 1.5 millimeters long. Wing about 7 millimeters wide and 6 millimeters long.

This distinctive winged seed is represented by the single specimen figured, from which the accompanying enlarged drawing has been made. Rather similar winged seeds occur in a number of existing families. The scars on the specimen show that several seeds were formed in a dry fruit-that is, a capsule-and the presence of wings indicates that it was dehiscent. This serves to distinguish the fossil from the samaras of the family Malpighiaceæ, which somewhat resemble it, particularly some modern forms of the genus Banisteria. Several existing forms of Bombacaceæ and Sterculiaceæ also show resemblances. Somewhat similar seeds with very much abbreviated wings have been referred by Heer and others to the genus Pterospermites of the family Sterculiaceæ.

The genus Embothrium Förster, which suggested the name for the fossil genus to Unger, comprises but few existing species of the South American Andean region, ranging from Peru to the Straits of Magellan, and one or two species of the mountains of tropical Western Australia. About a dozen fossil species from the European area, ranging from the upper Oligocene through the Miocene, have been referred to the living genus. Nine or ten fossil species have been referred to Embothrites. These are slightly older than the species referred to Embothrium, ranging from the Ligurian or Sannoisian (basal Oligocene) through the Oligocene into the Aquitanian, which by a number of recent students is made the basal part of the Miocene. All these species are from the European continent, where leaves and seeds are common, no authentic representative having heretofore been discovered in North America, although Hollick ${ }^{2}$ has described a Cretaceous leaf under the generic term Embothriopsis, and Lesquereux ${ }^{2}$ many years ago described a leaf from the Dakota sandstone of Kansas as Embothrium? daphneoides. Neither of these forms is very convincing evidence of the existence of the ances-

1 Hollick, Arthur, Additions to the paleobotany of the Cretaceous formation on Long Island: New York Bot. Gard. Bull., vol. 8, p. 159, pl. 165, fig. 1, 1912.

2 Lesquereux, Leo, Contributions to the fossil flora of the Western Territories, pt. 1, The Cretaceous flora, p. 87, pl. 30 , fig. 10, 1874. 
tors of Embothrium in the Upper Cretaceous flora of North America.

There are three species of seeds from the European Tertiary which especially resemble the present seed. These are Embothrites aquensis Saporta, ${ }^{1}$ from the Sannoisian of southeastern France; Embothrites boreale Unger, ${ }^{2}$ the type of the genus, an Aquitanian form of Croatia, Styria, and especially Greece, ${ }^{3}$ and Embothrites leptospermos Ettingshausen,,$^{4}$ which ranges from the Sannoisian lignites of Tyrol to the Aquitanian brown coal of Styria. The last is by far the closest to the American species and is well figured in basal Oligocene material from Tyrol. ${ }^{5}$ The present species, which differs from all previously described forms in the extent to which the proximal spur is developed, is named in honor of Franz Unger, who first described the genus.

Occurrence: Catahoula sandstone, Chalk Hills, 2 miles south of Rosefield, La.

Collection: New York Botanical Garden.

Order RANALES.

Family ANONACER.

Genus ANONA Linné.

Anona texana Berry, n. sp.

Plate LX, figure 9.

Leaves of large size, broadly ovate in general outline, with a pointed apex and a rounded base. Length about 15 or 16 centimeters; maximum width about 5.25 centimeters in the lower half of the leaf. From the region of maximum width the leaf narrows upward, but the tip is not extended. Margins entire, slightly undulate. Texture presumably coriaceous, but as these leaves are preserved as impressions in sandstone this is not certain. Petiole short and stout. Midrib stout, prominent on the lower surface of the leaf. Secondaries of considerable size but relatively thin, 8 to 10 pairs, irregularly spaced and usually remote; they diverge from the midrib at varying angles from $60^{\circ}$ to $70^{\circ}$ and are either regularly curved or relatively straight, campto-

\footnotetext{
1 Saporta, Gaston de, op. cit. (Études, etc.), vol. 1, p. 107, pl. 8, fig. 8, 1863.

2 Unger, F. J., Die fossile Flora von Sotzka, p. 41, pl. 21, figs. 10-12, 1859.

3 Unger, F. J., Die fossile Flora von Kumi, p. 37, pl. 9, fig. 23, 1867

4 Ettingshausen, Constantin, Die Proteaceen der Vorwelt, p. 19, pl. 2 , figs. $12,13,1851$

5 Ettingshausen, Constantin, Die tertiäre Flora von Häring in Tirol, p. 51 , pl. 14, figs. $15-25,1853$.
}

drome in the marginal region. A few transversely percurrent tertiaries are visible, but the bulk of the tertiary venation is obsolete. This is a well-marked species of Anona, somewhat resembling but entirely distinct from the various Anona leaves so common in the upper part of the middle Wilcox. It is also very similar to several existing species which are common in the American Tropics.

Occurrence: Fayette sandstone, three-quarters of a mile above the junction of Caney and White Rock creeks, Trinity County, Tex.

Collection: United States National Museum.

Order ROSALES.

Family MIMOSACER.

Genus PITHECOLOBIUM Martius.

Pithecolobium oligocænum Berry, n. sp.

Plate LV, figure 10.

Lsaves pinnate, with several pairs of opposite leaflets. Leaflets asymmetric-ovate in outline; widest in the middle part, where the lateral margins are full and rounded; narrowing rapidly both distad and proximad to form the equally pointed apex and base; the ultimate point of the former not acuminate but bluntly rounded. Length about 2.6 centimeters; maximum width about 1.7 centimeters. Margins entire. Texture subcoriaceous. Petiolule short and stout, about 2 millimeters in length. Midrib stout, curved, prominent on the lower surface of the leaflet. Secondaries stout, about five or six subopposite to alternate pairs, diverging from the midrib at angles of about $50^{\circ}$, curving upward, camptodrome in the marginal region, prominent on the lower surface of the leaflet. Tertiaries thin but well marked in the specimens, the meshes being exactly comparable with those of existing species of Pithecolobium with which they have been compared.

The genus Pithecolobium, which is more or less closely related to the genus Inga of Willdenow, has over 100 existing species, all confined to the Torrid Zone and many of them large trees. Three-fourths of the existing species occur in the American Tropics, but there are over a score in the Asiatic Tropics, and a few in the African and Australian Tropies. Up to the time of the present studies the genus had not been recognized in the fossil state. There are two well-marked species in the Wilcox 
flora of Mississippi and northern Tennessee, and the present species forms a link between these Wilcox species and the trees of the present-day American Tropics that have very similar leaves.

The species is not abundant in the rather small collections from this horizon.

Occurrence: Catahoula sandstone, Chalk Hills, 2 miles south of Rosefield, La.

Collection: New York Botanical Garden.

\section{Order GERANIALES.}

Family RUTACEF.

Genus FAGARA Linné.

The genus Fagara consists of numerous existing species of shrubs and trees, over 150 being known. They are cosmopolitan in tropical and subtropical countries and a few range into the Temperate Zone, especially in southeastern North America, where they have been confused with the closely allied genus Xanthoxylum Linné. Fossil forms based on foliage are usually referred to Xanthoxylum, and these number about 20 species, all of Tertiary age, mostly from the European Oligocene. The leaves in the two genera are much alike, the main distinction being the absence of a calyx in Xanthoxylum. This would indicate that Xanthoxylum is derived from Fagara by reduction of floral parts and by adaptation to cooler climates. I have elsewhere expressed the opinion that this evolution had not occurred in Eocene time, and I have described several species of Figara from the Upper Cretaceous and lower and middle Eocene of the Mississippi embayment. These species appear to be ancestral to the numerous representatives of this genus found in the lower Oligocene of Louisiana. The more argillaceous lenses in this lower part of the Vicksburg limestone in central Louisiana are crowded with leaflets of the Fagara type, suggesting the lagoons of southern Florida, where calcareous muds are accumulating and in the vicinity of which species of Fagara are among the commonest of coastal plants, as they are also throughout the Antilles and in Central America and northern South America.

The Oligocene material is diverse and might be differentiated into a score of species or described as one species according to the mental attitude of the student. After much study I have differentiated four forms as varieties of a central type for which the name Fagara catahoulensis is proposed. They are differentiated by characters which appear to be constant, notwithstanding the fact that all are represented by numerous specimens. They are all more or less inequilateral glandular punctate leaves, with grooved petiolules and a tendency toward revolute margins-all characters suggesting the Rutaceæ and distinguishing them from various genera of the Rhamnaceæ with which they might otherwise be compared. Their punctate character is well shown in some of the photographs reproduced in the present work.

Key to American Oligocene forms of Fagara.

Leaflets orbicular or elliptical. Secondaries few, five pairs or less..............Fagara catahoulensis orbiculata. Leaflets ovate or ovate-lanceolate:

Twice as long as wide, broadest midway between apex and base. Secondaries numerous, more than five pairs................Fagara catahoulensis elongata.

Less than twice as long as wide:

Secondaries few, five pairs or less,

Fagara catahoulensis coriacea. Secondaries numerous, more than five pairs, Faga catahoulensis major.

Fagara catahoulensis orbiculata Berry, n. var.

Plate LIX, figures 1-3.

Leaflets glandular punctate, of medium size for this genus, orbicular or elliptical in general outline, equally rounded at the apex and base. Length from 2.5 to 4 centimeters; maximum width, midway between the apex and the base, from 1.8 to 3.3 centimeters. Margins entire. Texture coriaceous. Petiolule short, stout, grooved, curved, about 3 millimeters in length. Midrib stout, curved or flexuous, prominent on the lower surface of the leaflet. Secondaries stout, prominent on the lower surface of the leaflet, four or five subopposite to alternate pairs, diverging from the midrib at angles ranging from $65^{\circ}$ in the lower part of the orbicular leaflets to $35^{\circ}$ in the upper part of some of the orbicular leaflets and in the elliptical leaflets; all camptodrome, usually at a considerable distance from the margin. Tertiaries thin but well marked, especially on the lower surface of the leaflets, forming open irregular meshes that are well shown in the small elliptical leaflet figured. Areolation of thin but distinct veinlets forming minute quadrangular or polygonal meshes. 
This form shows considerable variation from the typical orbicular leaflet figured, through the large leaflet in which the apex is somewhat ascending, toward Fagara catahoulensis major, and on the other hand the elliptical forms like the one figured approach Fagara catahoulensis elongata. These variants of orbiculata differ from both of these other forms in the fewer and more open secondaries and in their general outline, as is readily seen in the photographic reproductions of some of the specimens. They are much less common than any of the associated forms of Fagara.

Occurrence: Catahoula sandstone, Chalk Hills, 2 miles south of Rosefield, La.; Fayette sandstone, Stryker, Tex.

Collections: United States National Museum, New York Botanical Garden.

Fagara catahoulensis coriacea Berry, n. var.

Plate LIX, figures 8-10.

Leaflets glandular punctate, of small size, ovate-lanceolate, and slightly inequilateral in general outline, with a bluntly pointed apex and a broadly rounded base. Length from 1.75 to 2.75 centimeters, averaging about 2 centimeters; maximum width, below the middle of the leaflet, from 1.2 to 2 centimeters, averaging about 1.4 centimeters. Margins entire, slightly revolute in some specimens. Texture coriaceous. Petiolule very stout, grooved, curved, 3.5 millimeters in length. Midrib stout and curved, prominent on the lower surface of the leaflet. Secondaries stout and prominent, four or five mostly subopposite pairs; they diverge from the midrib at somewhat irregular intervals at angles ranging from $35^{\circ}$ to $60^{\circ}$, and pursue a straight course halfway to the margins where they curve upward; camptodrome in the marginal region. Tertiaries immersed in the leaf substance.

This well-marked form is less abundant in the collections than elongata or major but more abundant than orbiculata. It is much like major in general outline but is broader nearer the base, has fewer secondaries, and averages much smaller in size.

Occurrence: Catahoula sandstone, Chalk Hills, 2 miles south of Rosefield, La.

Collection: New York Botanical Garden.
Fagara catahoulensis major Berry, n. var.

Plate LIX, figures 4-7.

Leaflets glandular punctate, averaging of relatively large size, ovate-lanceolate and slightly inequilateral in outline, with an acutely pointed apex and a rounded or broadly pointed base. Length from 2.2 to 4.5 centimeters, averaging about 3.5 centimeters; maximum width, at or slightly below the middle, from 1.5 to 2.75 centimeters, averaging about 2.5 centimeters. Margins entire. Texture coriaceous. Petiolule stout, grooved, about 4.5 millimeters in length, in some specimens showing evidence of narrow, straight lateral wings. Midrib stout, prominent on the lower surface of the leaflet. Secondaries stout and prominent, about six pairs, subopposite below and usually alternate above; they diverge from the midrib at angles of about $45^{\circ}$, although there is considerable variation in this feature; they are for the most part regularly curved upward and subparallel and are camptodrome in the marginal region. Tertiaries mostly immersed in the leaf substance; a few percurrent ones visible.

This is the most common as well as the largest form in the collection and is represented by abundant material. It approaches elongata on the one hand and coriacea, as well as some of the more elongated forms of orbiculata, on the other.

Occurrence: Catahoula sandstone, Chalk Hills, 2 miles south of Rosefield, La.

Collections: United States National Museum, New York Botanical Garden.

Fagara catahoulensis elongata Berry, n. var.

Plate LIX, figures 11-15.

Leaflets glandular punctate, averaging of rather small size, narrowly ovate and inequilateral in general outline, nearly equally pointed at the apex and base, the apex sometimes slightly more pointed than the base. Length from 1.6 to 4.25 centimeters, averaging about 2.75 centimeters; maximum width, midway between the apex and the base, from 1 to 2 centimeters, averaging about 1.4 centimeters. Margins entire, slightly revolute. Texture coriaceous. Petiolule stout, grooved, curved, 
enlarged proximad, 3 to 4 millimeters in length. Midrib stout, usually curved, prominent on the lower surface of the leaflet. Secondaries stout, six or seven subopposite to alternate pairs, diverging from the midrib at angles of about $40^{\circ}$, subparallel, camptodrome in the marginal region. Tertiaries immersed in the leaf substance.

This form is more abundant than the varieties orbiculata and coriacea, but not as abundant as Fagara catahoulensis major. It resembles some of the forms of orbiculata as well as some of the variants of major but differs from both of these in its proportions.

Occurrence: Catahoula sandstone, Chalk Hills, 2 miles south of Rosefield, La.; Fayette sandstone, Stryker, Tex.

Collections: United States National Museum, New York Botanical Garden.

Order RHAMNALES.

Family RHAMNACE正.

Genus PALIURUS Jussieu.

Paliurus catahoulensis Berry, n. sp.

Plate LX, figures 1-4.

Leaves of small size, ovate to oblong-lanceolate in general outline, with a narrowed and acutely or bluntly pointed tip and a broadly rounded, somewhat inequilateral base. Length from 2.5 to 5 centimeters, averaging about 3 centimeters; maximum width, in the lower half of the leaf, from 7 millimeters to 2 centimeters. Margins entire. Leaf substance thin but apparently of considerable consistency. Petiole short, stout, and curved, about 2 millimeters in length. Midrib slender, somewhat flexuous. Lateral primaries thin, one on each side, diverging from the top of the petiole and forming an angle of $35^{\circ}$ with the midrib, curving upward parallel with the lateral leaf margin and becoming parallel with the midrib, extending above the middle of the leaf, terminating by joining a secondary. Secondaries thin, three or four subopposite to alternate pairs in the upper half of the leaf, diverging from the midrib at angles of about $50^{\circ}$, curved regularly upward, camptodrome in the marginal region. Tertiaries forming open camptodrome arches from the outside of the lateral primaries in the marginal region; internally they are thin, numerous, transverse in direction, nearly straight or inosculating.
This well-marked species has smaller leaves than the majority of described fossil species, but it may be matched by several existing forms in this and the allied genus Zizyphus.

In the existing flora Paliurus is represented by two species, one confined to China and Japan and the other extending westward into southern Europe. About 30 fossil species based on both leaves and the characteristic fruits are known, some of which extend back in time to the middle Cretaceous. Zizyphus, which in the absence of fruiting specimens is not distinguishable with certainty from Paliurus, has about 40 existing species confined largely to the IndoMalayan Tropics, only a single species occurring in the American Tropics. It has numerous fossil species. Both genera are well represented in the Eocene floras of the Mississippi embayment.

At the same locality and horizon which furnished the leaves a fragment of a slender flexuous thorned stem was collected. While I realize that this might belong to a variety of unallied genera, its character and association have led me to refer it tentatively to this species. It may be compared with the almost identical remains from the Sannoisian of Aix, in southeastern France, which Saporta ${ }^{\prime}$ referred to Paliurus tenuifolius Heer.

Occurrence: Catahoula sandstone, Chalk Hills, 2 miles south of Rosefield, La.

Collection: New York Botanical Garden.

Order MYRTALES.

Family MYRTACE正.

Genus MYRCIA De Candolle.

Myrcia catahoulensis Berry, n. sp.

Plate LX, figures 5, 6 .

Leaves of small size, linear-lanceolate, and often somewhat falcate in general outline, with a gradually narrowed and acuminate apex and a similarly pointed base. Length from 4.5 to 7 centimeters; maximum width, in the middle part of the leaf, 5 millimeters to 1.1 centimeters. Margins entire. Texture coriaceous. Petiole missing. Midrib stout, somewhat prominent on the lower surface of the leaf. Secondaries thin, immersed in the substance of the leaf and seen only with difficulty,

1 Saporta, Gaston de, op. cit. (Études, etc.), vol. 3, suppl. 1, p. 98, pl. 16, figs. 12, 13, 1867 . 
their tips joined by an acrodrome marginal vein on each side close to the margin and, like the secondaries, nearly obsolete by immersion in the leaf substance.

This species is represented by several fragmentary specimens in the Chalk Hills collection, two of which, showing the extremes of size, are figured. The oldest beds in which the genus has been definitely recognized are those of the Wilcox group, but it is probably represented in Upper Cretaceous floras by some of the forms referred to the genus Eucalyptus. It is an abundant element in the Wilcox flora, being represented by four described species, among which Myrcia bentonensis Berry, a form found along the shores of the Mississippi embayment from central Arkansas to northern Mississippi, is most like the present species. It is, however, always larger, usually much larger, and is more obtusely pointed.

The genus Myrcia is the most varied existing American genus of the Myrtaceæ, having more than 400 tropical species, massed in northern South America, but extending southward to Uruguay and Chile and northward through the West Indies. The present fossil form may be compared with a number of still-existing American species, and it is evident that the genus was present in the flora of tropical and subtropical America from the dawn of the Eocene down to the present time, invariably extending its range northward over southeastern North America whenever the climatic conditions were favorable.

Occurrence: Catahoula sandstone, Chalk Hills, 2 miles south of Rosefield, La.

Collections: United States National Museum, New York Botanical Garden.

\section{Order EBENALES.}

Family SAPOTACE⿸⿻

Genus BUMELIA Swartz.

\section{Bumelia vicksburgensis Berry, n. sp.}

Plate LX, figure 7.

Leaves of small size, elliptical, almost orbicular in general outline, with an emarginate tip and a broadly rounded base. Length about 1.2 centimeters; maximum width, at a point about midway between the apex and the base, about 1 centimeter. Margins entire, inclined to be slightly revolute. Texture very coriaceous. Petiole wanting. Midrib stout, slightly curved. Secondaries thin, immersed in the leaf substance, four or five pairs, diverging from the midrib at wide angles and camptodrome in the marginal region. Tertiaries completely immersed.

The present species is small for this genus and superficially resembles various leguminous leaflets such as those of the genera Dalbergia and Colutea.

The genus Bumelia is confined to America in the existing flora and comprises about 20 species scattered from the southern United States through the West Indies and Central America to Brazil. Its geologic history ranges from the Upper Cretaceous to the present and although it is exclusively American in the Recent flora it is well represented in the European Tertiary. There are four wellmarked species in the flora of the Wilcox group, one of which, Bumetia pseudohorrida Berry, is very similar to the present species. Among recent species Bumelia horrida Grisebach, of the West Indies, is close to the present species, its chief difference being the possession of a petiole.

Occurrence: Catahoula sandstone, Chalk Hills, 2 miles south of Rosefield, La.

Collection: New York Botanical Garden.

Genus CARPOLITHUS Stokes and Webb.

Carpolithus bumeliaformis Berry, n. sp.

Plate LX, figure 8.

Fruit oblate-spheroidal, nearly globose, about 7.5 millimeters in maximum diameter (length) and 5.75 millimeters in minimum diameter. Seed large, nearly globose, crustaceous; flesh thin and dry.

The present species is based on only a few specimens which agree remarkably well with the fallen fruits of those of our American species of Bumelia that have dry instead of fleshy fruits.

The genus Bumelia is a prominent element in the earlier Tertiary floras of southeastern North America, the leaves of one species being associated with the present fruits. As the nature of the remains precludes certainty of identification I have referred these fruits to the convenient form genus Carpolithus and have emphasized their supposed botanic affinity in the specific name.

Occurrence: Catahoula sandstone, Chalk Hills, 2 miles south of Rosefield, La.

Collection: New York Botanical Garden. 


\section{PLATES LV-LX.}




\section{PLATE LV.}

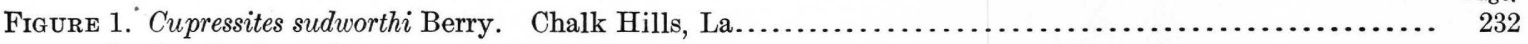

2. Pestalozzites minor Berry. Chalk Hills, La . . . . . . . . . . . . . . . . . . . . . . . . . 230

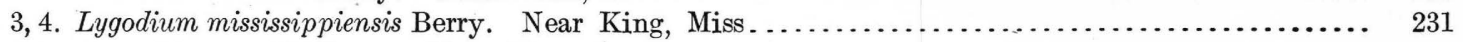

5-8. Acrostichum smithi Berry. Near King, Miss................................... 231

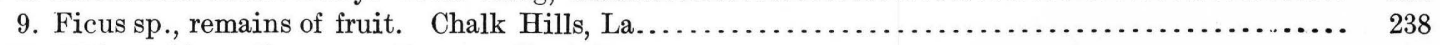

10. Pithecolobium oligocænum Berry. Chalk Hills, La.............................. 239

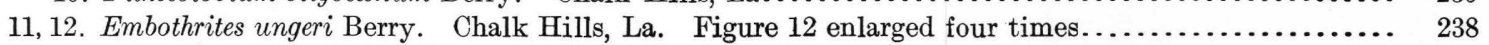

All from Catahoula sandstone. 


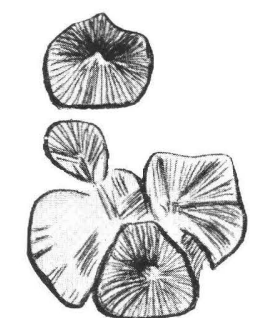

1

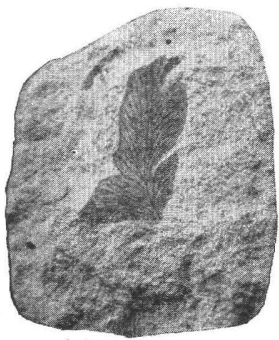

4
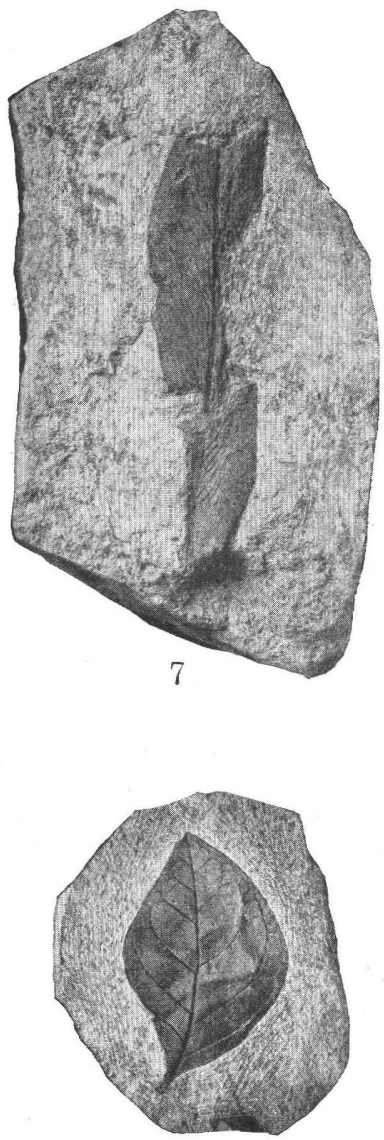

10
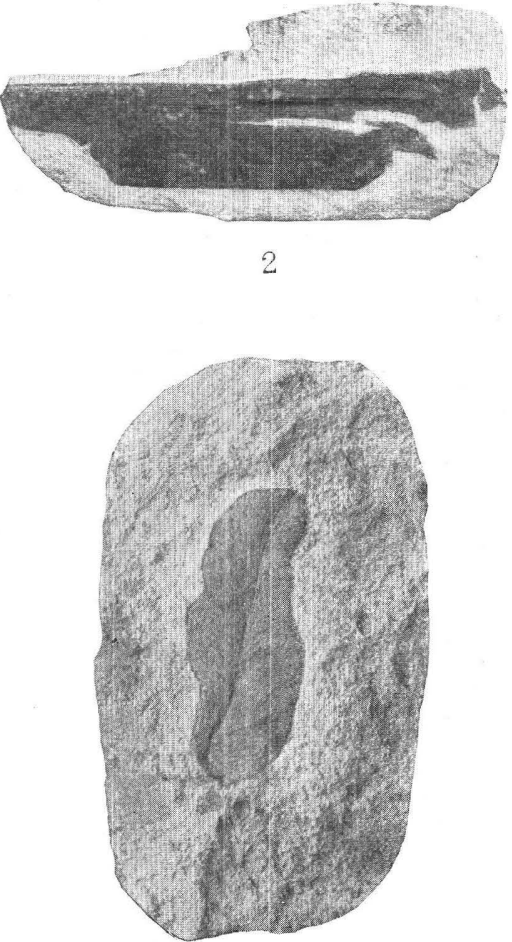

5

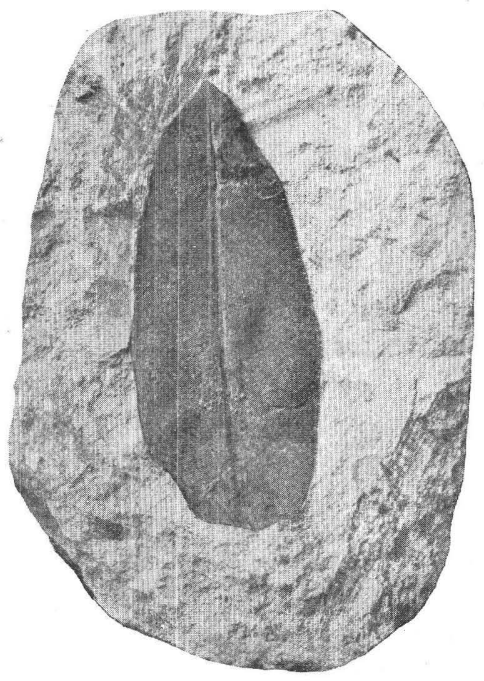

8

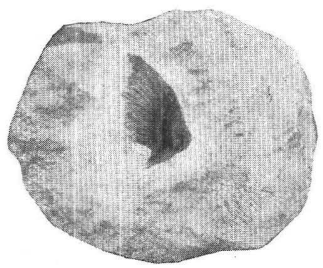

11

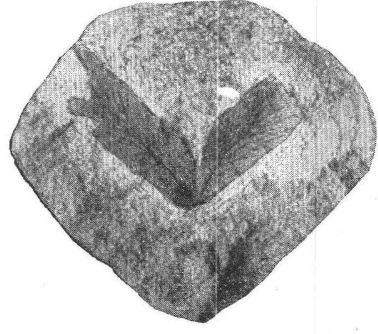

3

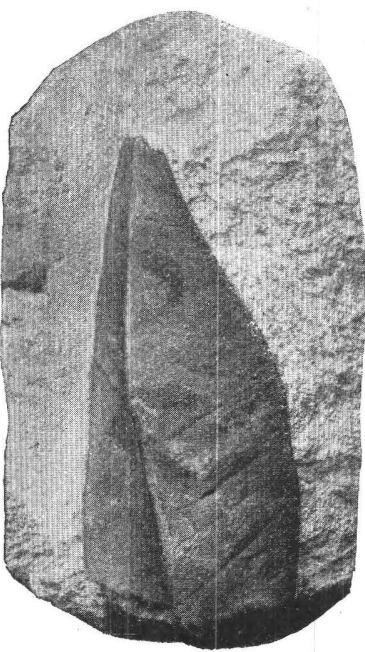

6

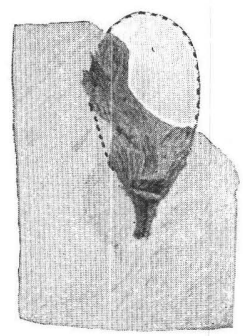

9

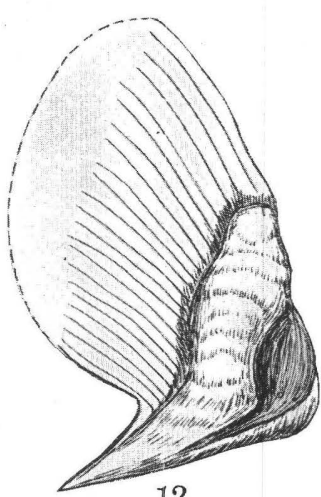

12 


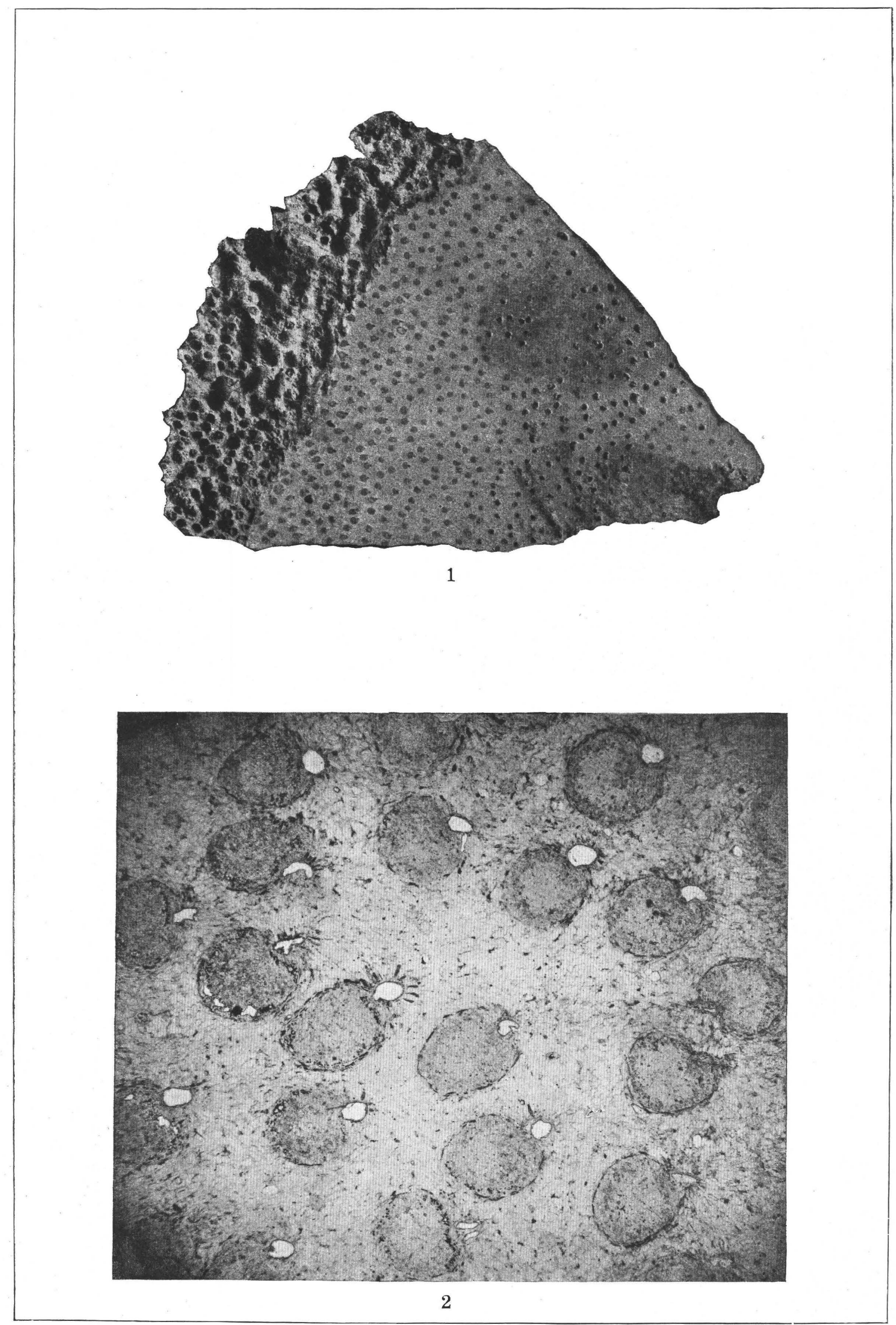

FOSSILS OF THE CATAHOULA SANDSTONE. 


\section{PLATE LVI.}

Figures 1, 2. Palmoxylon texense Stenzel. Near Jasper, Tex. Figure 1, natural size; figure 2, transverse section, enlarged 10 times. From Catahoula sandstone . . . . . . . . . . . . . . . . . . . . . . . . . 
PLATE LVII.

Figure 1. Palmoxylon lacunosum (Unger) Felix. Near Pollock, La. Fibrovascular bundle; enlarged 50

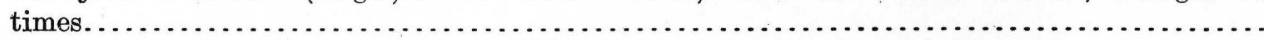
2-5. Palmoxylon remotum Stenzel. Five miles north of Waynesboro, Miss. Showing variations in

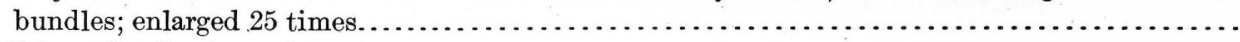
All from Catahoula sandstone.

Page. 236 248 


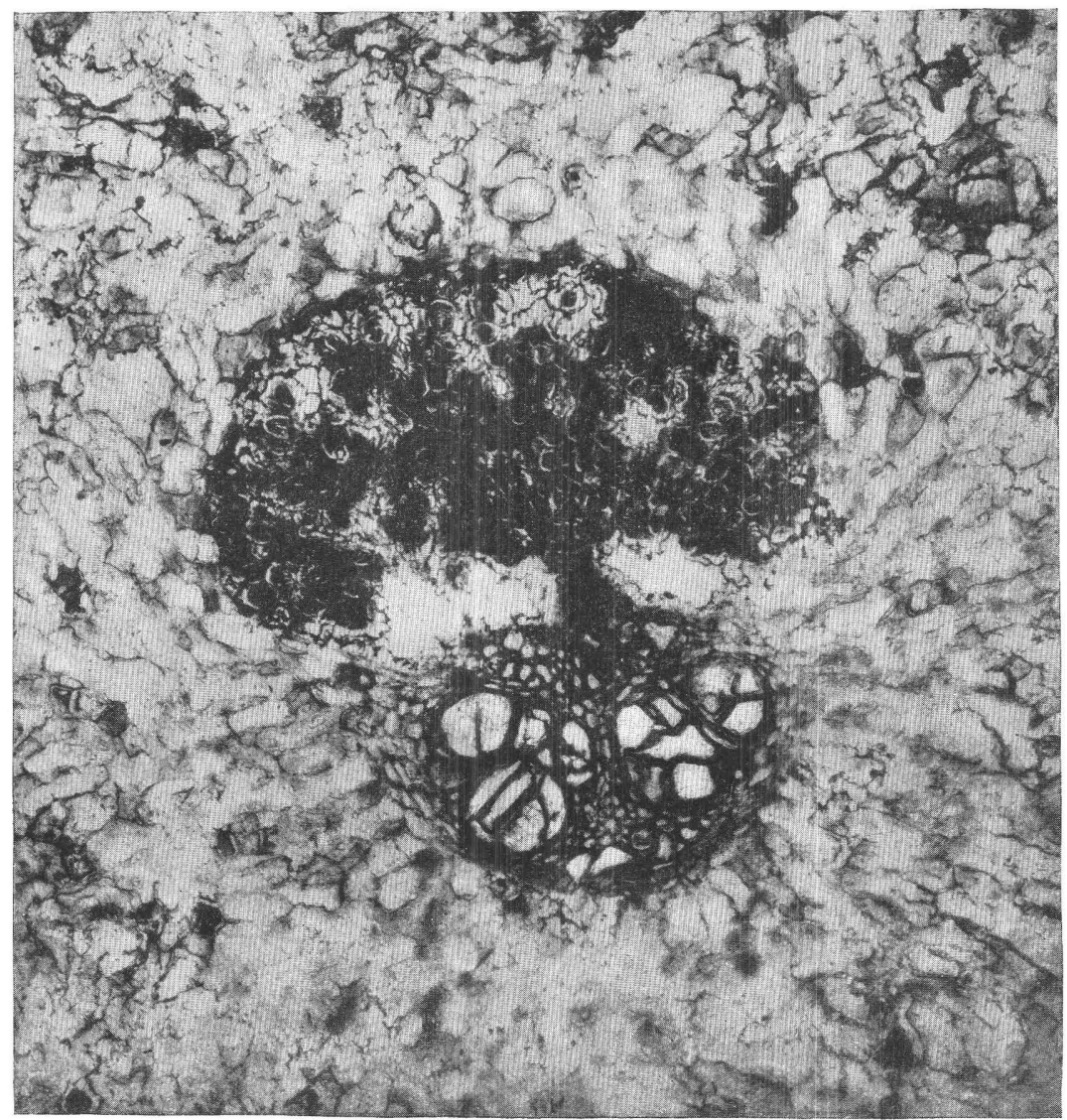

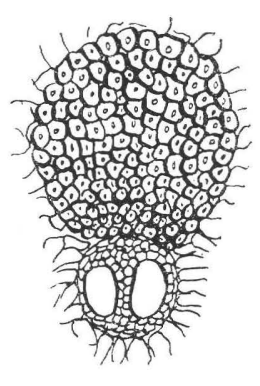

2

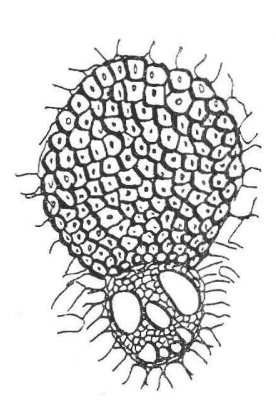

3

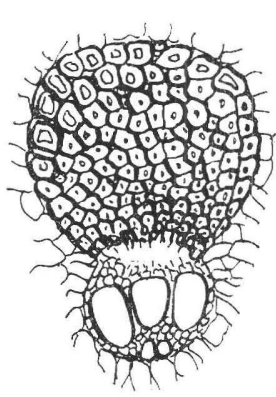

4

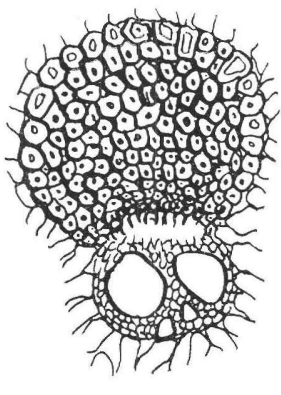

5

FOSSILS OF THE CATAHOULA SANDSTONE. 

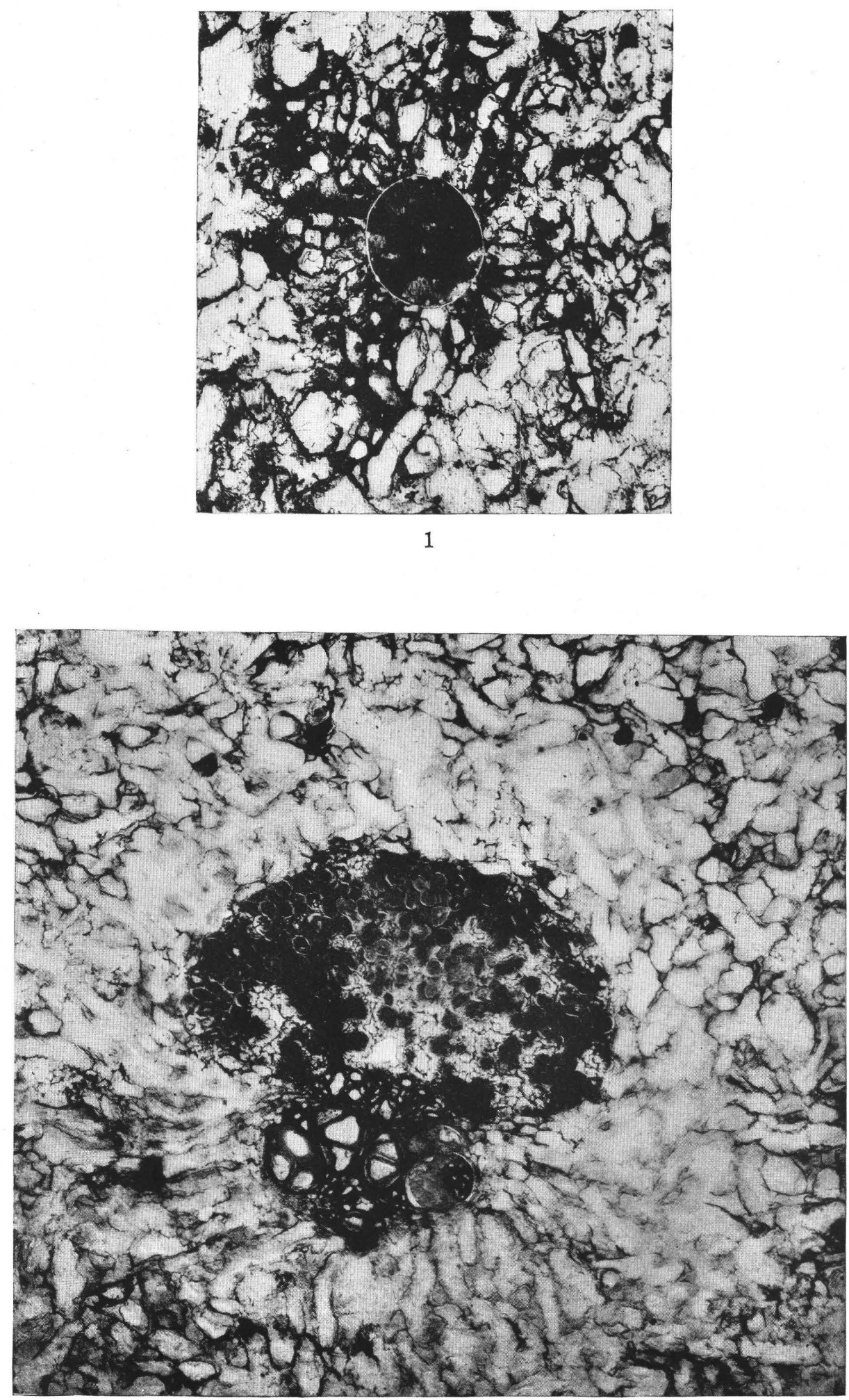


\section{PLATE LVIII.}

Page.

Figures 1, 2. Palmoxylon lacunosum (Unger) Felix. Near Pollock, La. Figure 1, auxiliary bundle; enlarged 50 times. Its sharp boundary is due to the manner in which the negative has been retouched and is not shown by the material. Figure 2, transverse section of primary bundle;

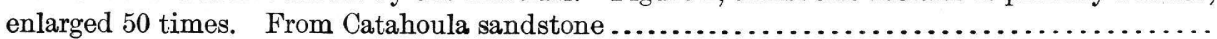


PLATE LIX.

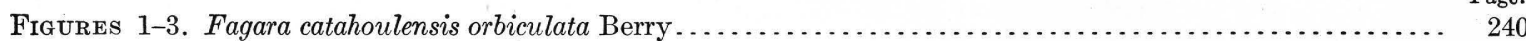

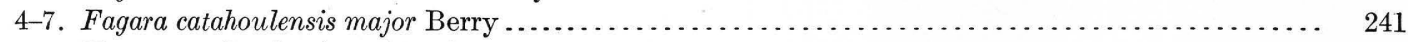

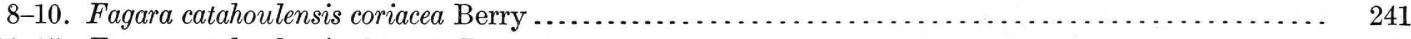

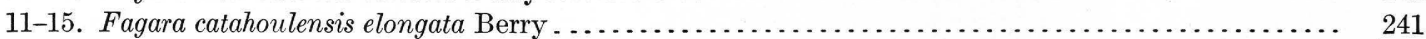

All from Catahoula sandstone at Chalk Hills, La. 250 


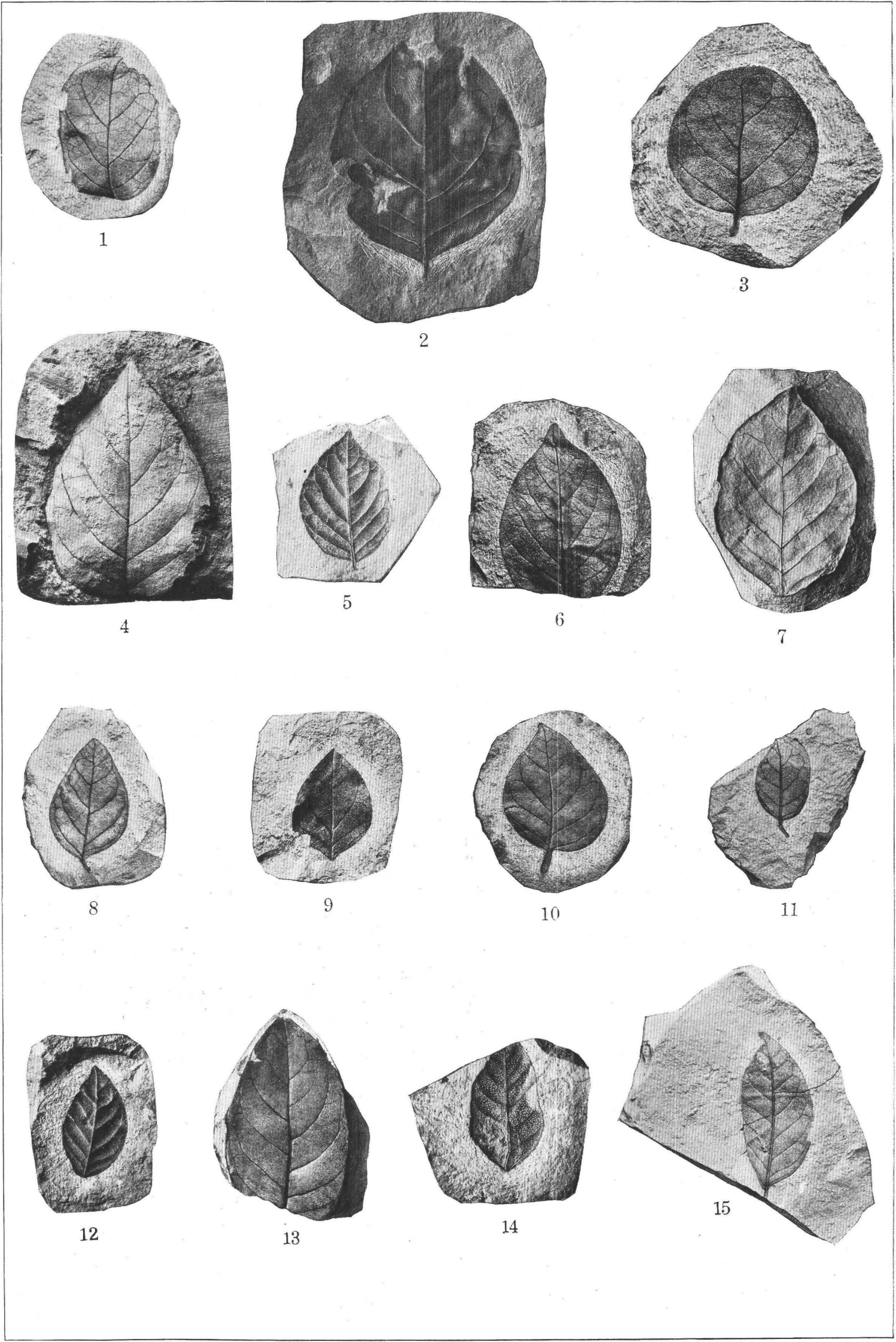

FOSSILS OF THE CATAHOULA SANDSTONE. 


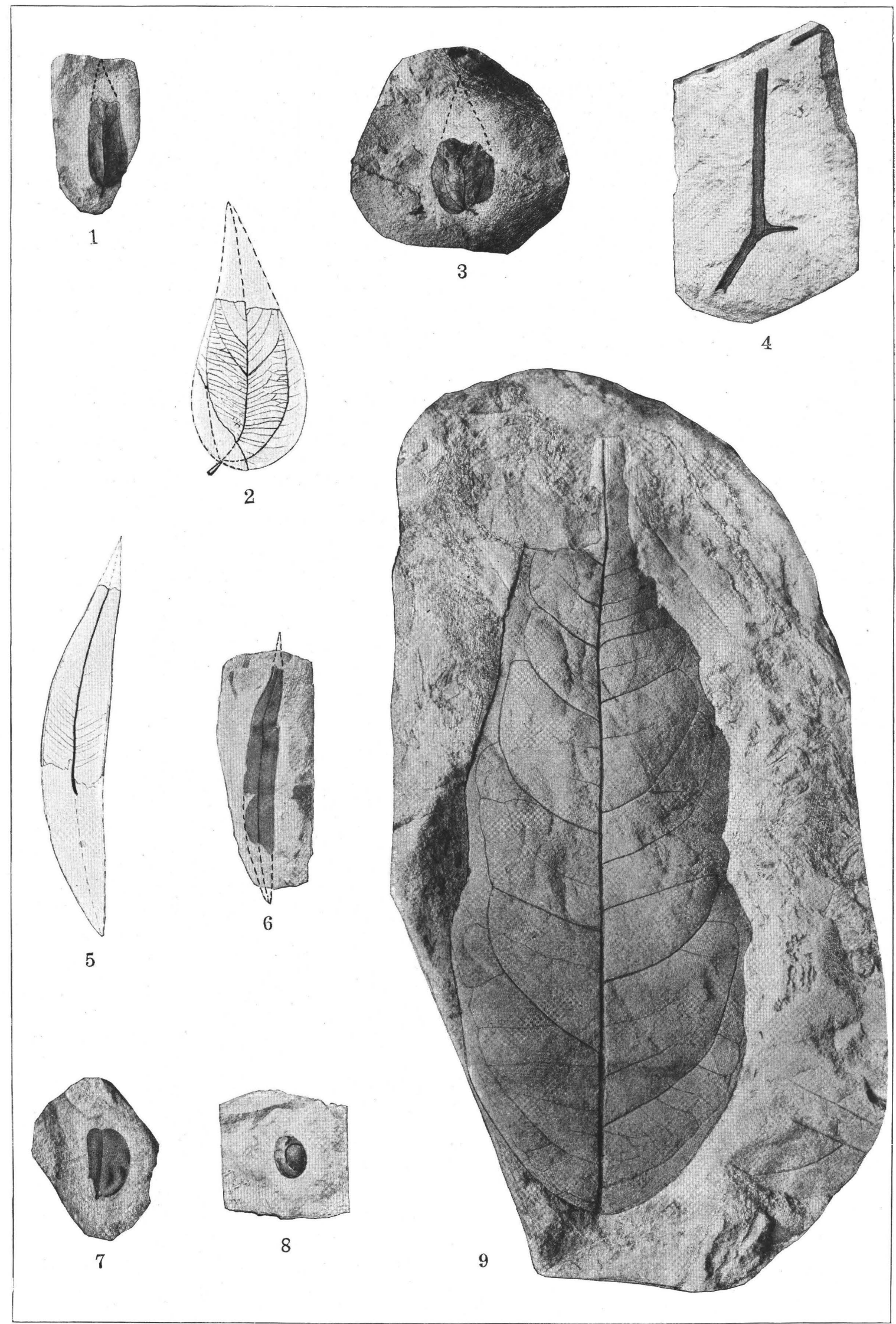

FOSSILS OF THE CATAHOULA AND FAYETTE SANDSTONES. 
PLATE LX.

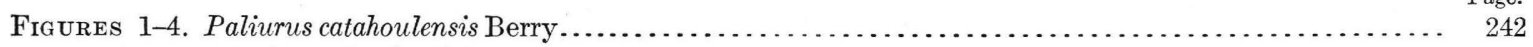

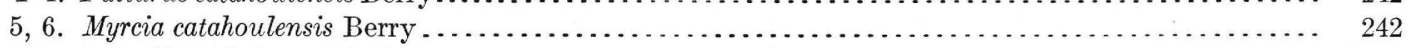

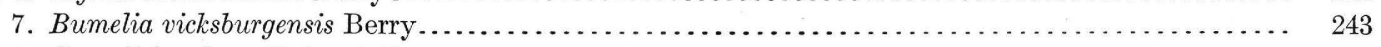

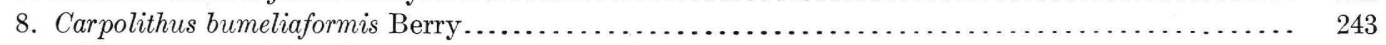

Figures 1 to 8 from Catahoula sandstone, Chalk Hills, La.

9. Anona texana Berry. Fayette sandstone of Trinity County, Tex. . . . . . . . . . . . . . 239

$30830^{\circ}-17-17$ 